https://journal.uwgm.ac.id/index.php/abdimasmahakam

E-ISSN: 2549-5755

Januari 2020, Vol. 4 No. 01

Received: September 2019

Accepted: November2019

Published: Januari 2020

Article DOI: http://dx.doi.org/ 10.24903/jam.v4i1.769

\title{
Sosialisasi Pentingnya Mengenal dan Mengembangkan Potensi Anak Sejak Dini bagi Warga di Kampung Cerdas
}

\author{
Gamar Al Haddar \\ Universitas Widya Gama Mahakam Samarinda \\ gamar@uwgm.ac.id \\ Ratna Khairunnisa \\ Universitas Widya Gama Mahakam Samarinda \\ nhanarisa@gmail.com
}

\begin{abstract}
Abstrak
Setiap anak pasti memiliki potensi yang dapat diasah dan digali secara mendalam. Salah satu peran utama orang tua adalah menggali potensi yang dimiliki oleh anaknya. Dalam kegiatan pengabdian ini orang tua dikenalkan dengan delapan ragam kecerdasan sebagaimana teori gadner. Setelah dikenalkan kemudian diberikan pemahaman cara mengenal dan mengembangkan potensi tersebut. Kegiatan pengabdian ini dilaksanakan di kampung cerdas yang berlokasi di Jalan KH Wahid Hasyim RT 08 Keluarahan Sempaja Selatan, Kecamatan Samarinda Utara, Kota Samarinda. Tujuan Penelitian ini adalah memberikan informasi kepada orang tua warga di kampung cerdas tentang cara dan manfaat yang diperoleh dengan mengenal dan mengembangkan potensi anak sejak dini. Berdasarkan hasil kegiatan yang telah dilakukan orang tua dapat mengetahui jenis jenis kecerdasan yang dimiliki oleh setiap anak yakni kecerdasan bahasa, kinestetik, visual, interpersonal, intrapersonal, angka, musikal dan natural. Setelah sosialiasi dilakukan Orang tua juga memiliki pemahaman dan pengetahuan tentang cara mengenal dan mengembangkan kecerdasan anaknya sejak dini. Para warga di kampung cerdas juga dapat mengetahui karir yang cocok dan sesuai dengan kecerdasan yang dimiliki oleh anaknya. Dengan demikian orang tua menjadi lebih serius dalam mendidik anaknya. Sehingga anak dapat tumbuh dan berkembang dengan baik dan benar serta perkembangan aspek yang lainnya juga tercapai.
\end{abstract}

Kata Kunci: Kecerdasan Anak; Potensi.

\section{Pendahuluan}

Salah satu peran terpenting bagi orang tua adalah mengenali potensi yang dimiliki oleh anaknya. Sebagai orang tua yang bijaksana hendaknya kita mengetahui apa saja yang menjadi potensi anak dan mampu mengarahkan serta membimbing bakat potensi anak tersebut. Namun pada kenyataannya masih banyak orang tua yang belum mengetahui manfaat dan cara mengenali potensi anak. Dalam kegiatan sosialiasi ini tim pengabdi akan mengenalkan kepada orang tua cara yang tepat dan bijak untuk mengenali dan mengembangkan potensi yang dimiliki oleh anak anak mereka. 


\section{(A) ABDIMAS \\ https://journal.uwgm.ac.id/index.php/abdimasmahakam}

E-ISSN: 2549-5755

Januari 2020, Vol. 4 No. 01

Dalam kegiatan sosialiasi pengenalan dan pengembangan potensi anak sejak dini, kami memilih kampung cerdas sebagai target pengabdian masyarakat. Kampung cerdas merupakan salah satu kampung binaan universitas Widya Gama Mahakam Samarinda yang berlokasi di jalan K.H Wahid Hasyim RT 08 kelurahan 08 kelurahan Sempaja Selatan Kecamatan Samarinda Utara. Dalam hal ini kami akan mengenalkan dan mensosialiasikan tentang pentingnya mengenal potensi anak sejak dini. Selain itu kami juga akan membekali para orang tua dengan metode yang praktis dalam mengembangkan potensi yang dimiliki oleh anaknya.

Sangatlah penting jika orang tua memahami terlebih dahulu potensi anaknya secara mendalam kemudian setelah mengenalnya barulah oramg tua dapat membantu mengembangkan potensi anak sehingga dapat berkembang dengan optimal. Jangan sampai anak yang suka dibidang seni tapi oleh orang tuanya dipaksan diarahkan ke bidang matematika atau bidang yang lainnya. Hendaknya kemampuan seninya diasah sehingga anak ini mampu unggul dengan kelebihan dari potensi yang dimilikinya.

Dalam kegiatan sosialisasi ini pengabdi melaksanakan kegiatan sosialiasasi ini dengan cara yang asyik dan menyenangkan, sehingga para warga kampung cerdas khususnya orang tua dapat mengikuti kegiatan dengan suasana yang asyik dan nyaman. Setelah mengikuti kegiatan ini penelitian berharap nantinya para orang tua dapat menerapkan ilmu yang diperoleh untuk mengembangkan potensi anak anak mereka.

\section{Metode}

Metode yang diterapkan dalam kegiatan ini adalah sosialisasi. Dalam beberapa tahapan dalam kegiatan sosialisasi yakni penyajian materi, dan diskusi. Dalam kegiatan pengabdian ini metode pengambilan data yakni observasi dan wawancara langsung saat kegiatan sosialiasi berlangsung dan setelah kegiatan selesai dilaksanakan. Pelaksanaan pengabdian masyakat ini dilaksanakan pada bulan Maret sampai April 2019 bertempat di Kampung Cerdas yang berlokasi di Jalan KH Wahid Hasyim RT 08 Keluarahan Sempaja Selatan, Kecamatan Samarinda Utara, Kota Samarinda.

\section{Hasil dan Pembahasan}

\section{Tahap Awal}

Kegiatan sosialiasi dimulai dengan izin kepada ketua RT 008 yakni bapak Mujadi pada tanggal 28 Februari 2019. Kemudian peneliti mengadakan pendekatan terhadap warga setempat yang menjadi target sosialiasi yakni orang tua yang ada di lingkungan RT 008 Jln. KH Wahid hasyim Gang Kampus Biru. Pada tahap awal peneliti aktif mengikuti kegiatan majlis yang diadakan oleh ibu ibu di lingkungan RT 008. Kegiatan rutin diadakan setiap hari jumat pukul 13.00. Tujuannya adalah melakukan pendekatan secara personal agar mengetahui berbagai problem yang sering dihadapi oleh orang tua dalam mendidik anaknya khususnya di kampung cerdas.

Bapak dan ibu RT memberikan banyak bantuan terutama dalam menyambungkan komunikasi antara tujuan pengabdian yang akan kami lakukan dengan kebutuhan masyarakat sekitar. Bapak dan Ibu RT juga ikut membantu kami menyebarkan undangan kegiatan sosialiasi yang kami laksanakan. Adapun Tempat sosialiasi juga dibantu disiapkan oleh bapak RT sebagai wujud positif dan antusias atas kegiatan sosialiasi yang kami laksanakan. 


\section{(A) ABDIMAS}

https://journal.uwgm.ac.id/index.php/abdimasmahakam

E-ISSN: 2549-5755

Januari 2020, Vol. 4 No. 01

\section{Tahap Pelaksanaan}

Kegiatan pengabdian dilaksanakan pada hari Minggu tanggal 21 April 2019. Waktu pelaksanaannya yakni dimulai dari pukul 15.30 sampai 18.00 WITA. Kegiatan sosialiasi dilaksanakan di aula musholla miftakhul ulum yang terletak di Jln. KH Wahid hasyim Gang Kampus Biru Samarinda.

Kegiatan berjalan lancar dan sukses sesuai harapan. Warga sangat aktif dan antusias terutama pada sesi diskusi. Pada 1 jam pertama, tim pengabdi menjelaskan materi tentang macam macam kecerdasan yang dimiliki oleh anak yakni kecerdasan naturalistik, matematik, visual, kinestetik, personal, interpersonal, linguistik dan musikal. Terlihat ibu ibu yang hadir mendengarkan pemaparan dengan sungguh sungguh. Tim pengabdi menggunakan bantuan layar proyektor untuk menampilkan materi dengan tujuan agar peserta yang hadir dapat lebih fokus. Peneliti menampilkan juga gambar gambar contoh pekerjaan dari masing masing hasil pendalaman potensi anak. Tim pengabdi juga menjelaskan ciri ciri anak yang memiliki masing masing kecerdasan tersebut dan pekerjaan yang cocok bagi masing masing kemampuannya sesuai potensinya.
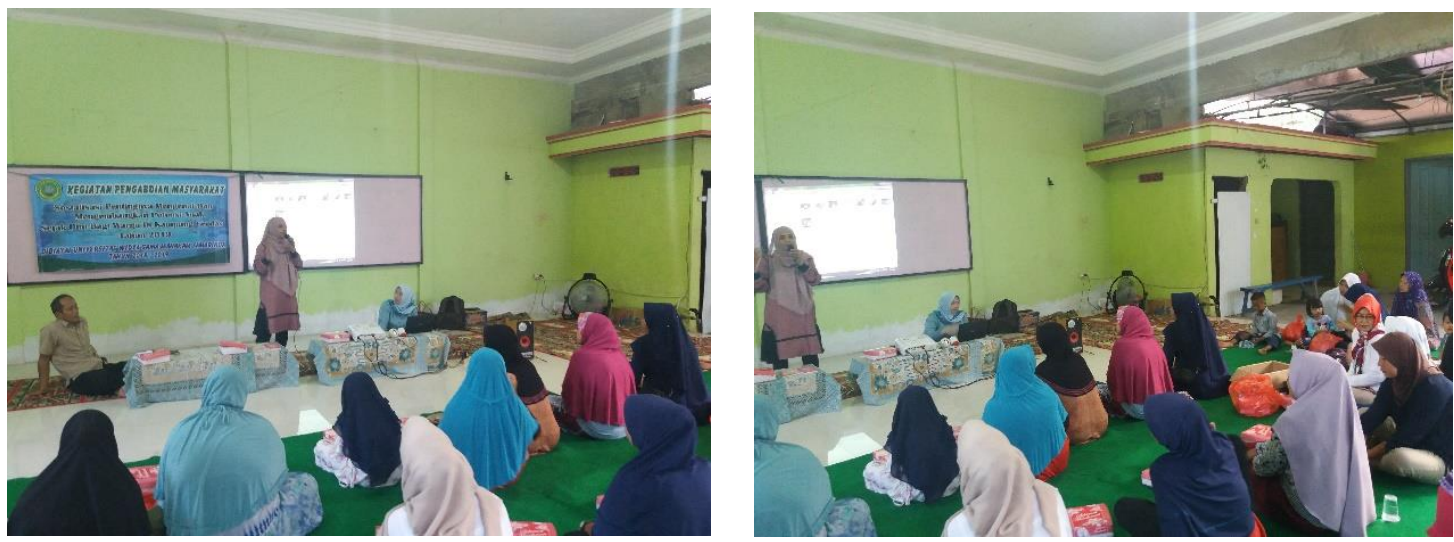

Gambar 1. Kegiatan Sosialisasi kepada warga di kampung Cerdas

Sesi diskusi menjadi sesi paling menarik karena banyak yang bertanya mengenai problem yang dihadapi mereka terutama yang berkaitan dengan anaknya. Ada yang bertanya mengenai cara untuk mengatasi bullying dari teman teman anaknya. Karena bullying ini dapat menghambat proses pengembangn potensi anak. Kemudian tim pengabdi memberikan pemahaman bahwa bullying ini merupakan satu hal yang dapat mematikan potensi anak. Oleh karena itu sebagai orang tua hendaknya menjalin komunikasi yang intensif dengan anak, guru dan teman teman anak kita. Tujuannya adalah mengetahui perkembangan anak kita di lingkungannya. Sebagai orang tua hendaknya tidak mengajarkan hal hal negatif kepada anaknya, misalnya melawan dengan membullying juga itu bukan solusi. Solusi yang tepat adalah melawan dengan prestasi. Orang tua hendaknya tidak pernah lelah untuk memotivasi anaknya secara terus menerus agar potensi yang dimiliki anak terasah dan dapat mengahsilkan sesuatu yang positif.

Pada sesi diskusi ada 6 orang warga yang bertanya. Masing masing pertanyaan memiliki banyak masalah terutama dalam tahapan mengenal potensi anak. Tim Pengabdi menjelaskan cara cara yang mudah untuk mengenali potensi anak ini. Potensi ini dapat kita lihat dalam keseharian anak anak di rumah, sekolah maupun di lingkungan masyarakat. 


\section{(A) ABDIMAS \\ https://journal.uwgm.ac.id/index.php/abdimasmahakam}

E-ISSN: 2549-5755

Januari 2020, Vol. 4 No. 01

\section{Penutupan}

Kegiatan sosialiasi diakhiri dengan memberikan apresiasi kepada warga yang bertanya. Setiap penanya mendapatkan hadiah 1 buku bacaan. Kami menyiapakan ada 6 buku bacaan orang tua dalam hubungannya dengan mendidik anak. Kegiatan ditutup dengan menulis catatan tentang potensi anak masing masing di kertas. Orang tua diajak langsung melakukan identifikasi atas potensi yang dimiliki oleh anak anak mereka. Kemudian kami mengarahkan orang tua untuk memahami masing masing pekerjaan dan aktivitas yang sesuai dengan potensi yang dimiliki.

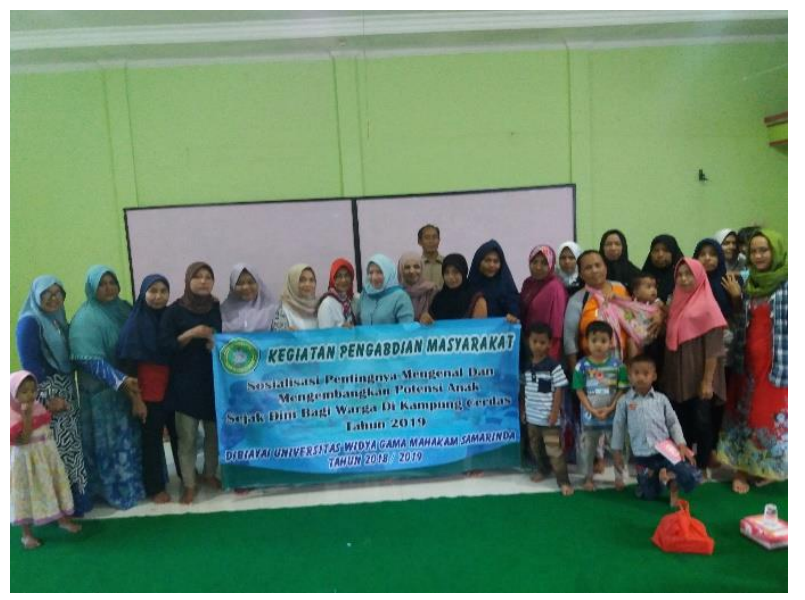

Gambar 2. Bersama warga kampung cerdas setelah kegiatan pengabdian

Anak merupakan anugerah Tuhan yang dititipkan kepada setiap orang tua. Tidak ada satupun anak yang bodoh di dunia ini. Setiap anak memiliki kemampuan yang berbeda-beda. Selain itu setiap anak juga pasti memiliki kelebihan dan kekurangan masing masing. Salah satu cara untuk menggali potensi anak adalah dengan tidak membanding bandingkan anak kita dengan orang lain.

Dalam kegiatan sosialiasi ini para orang tua diberikan wawasan tentang apa itu kecerdasan bahasa, kinestetik, visual, musik, interpersonal, personal dan natural. Anak yang cerdas bahasa adalah anak yang lincah dan pandai dalam menggunakan bahasa baik secara lisan maupun tulisan. Anak yang cerdas bahasa banyak berbicara, sering mnceritakan ulang informasi yang diterimanya dan suka berdiskusi. Terkadang ketika orang tua menemui anak tipe seperti ini maka akan sangat baik jika diarahkan ke bidangnya. Banyak orang tua yang hadir dalam kegiatan sosialiasi mengatakan anaknya cerewet. Padahal cerewet ini merupakan sebuah potensi yang dapat digali dan dikembangkan.

Anak yang cerdas kinestetik adalah anak yang aktifdan tidak bisa diam. Tipe anak cerdas kinestetik ini umumnya menyukai pembelajaran olah raga karena berhubungan dengan gerak. Ada orang tua yang hadir mengatakan anaknya gelisah kalau duduk teralalu lama dan lebih suka berkeliling dan jalan. Hal ini juga merupakan salah satu kecerdasan yang dapat dikembangkan dari seorang anak. Jika anak memiliki tanda seperti ini maka anak ini dapat digolongkan cerdas kinestetik.

Anak yang cerdas visual adalah anak yang suka sekali dengan sesuatu yang dapat dilihat secara nyata. Misalnya suka menggambar, mewarnai dan lainnya. Orang tua yang hadir juga menyebutkan bahwa ada salah satu anaknya yang suka membaca tetapi yang dilihat bukan 
https://journal.uwgm.ac.id/index.php/abdimasmahakam

E-ISSN: 2549-5755

Januari 2020, Vol. 4 No. 01

tulisannya melainkan gambarnya. Hal ini menunjukkan salah tanda bahwa anak cerdas visual. Adapun Anak yang cerdas musikal adalah adalah anak yang menyukai berbagai hal yang berhubungan dengan musik. Pandai dalam memainkan alat musik. Anak tipe ini merupakan tanda bahwa anak memiliki kecerdasan musik.

Ada juga orang tua yang menceritakan kebiasaan anaknya yang memiliki banyak kawan, pandai dalam bergaul, suka sekali membantu teman temannya terutama saat dalam kesusahan. Hal ini menunjukkan bahwa anak memiliki kecerdasan interpersonal. Sebaliknya ada orang tua yang hadir curhat dan mengatakan bahwa anaknya lebih suka mandiri, tidak banyak memiliki teman, lebih suka main sendiri dibandingkan bermain bersama sama, hal ini juga merupakan kecerdasan yakni cerdas personal.

Kecerdasan yang lainnya adalah cerdas angka. Jika anak suka sekali pembelajaran matematika dan suka berhitung maka ini juga merupakan salah satu tanda anak cerdas matematika. Cerdas yang lainnya adalah cerdas natural yakni mencintai alam bebas. Pada saat tim pengabdi mempresentasikan hal ini, banyak orang tua yang mengatakan anaknya suka berkemah, suka ke pantai. Kebiasaan ini merupakan salah satu tanda anak cerdas naturali.

Dengan pengenalan berbagai kecerdasan di atas orang tua menjadi memiliki pemahaman bahwa anak memiliki kelebihan dan kekurangan. Walaupun anak tersebut adalah anak berkebutuhan khusus maka secara otomatis pasti memiliki minimal satu kecerdasan. Dan anak anak yang normal lainnya bisa memiliki dua, tiga, empat bahkan banyak kecerdasan.

\section{Simpulan dan rekomendasi}

Kegiatan sosialiasi pentingnya mengenal dan mengembangkan potensi anak sejak usia dini berjalan lancar dan sukses serta mendapatkan apresiasi yang sangat luar biasa dari warga di kampung cerdas. Dengan adanya Kegiatan sosialiasi ini maka warga memperoleh informasi tentang manfaat yang diperoleh dari mengenal dan mengembangkan potensi anak sejak dini. Selain itu, dengan adanya kegiatan sosialisasi ini maka warga yang ada di kampung cerdas mengetahui cara yang tepat dan praktis untuk mengenal dan mengembangkan potensi yang dimiliki oleh anaknya sejak dini. 


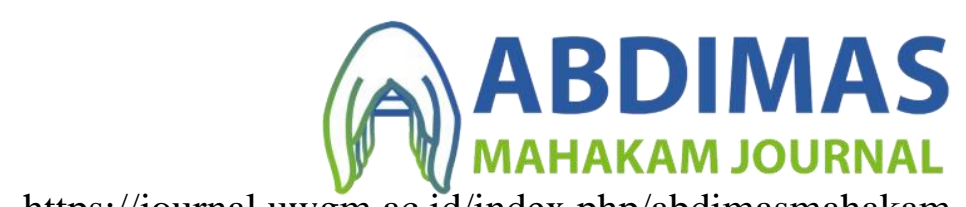

https://journal.uwgm.ac.id/index.php/abdimasmahakam

E-ISSN: 2549-5755

Januari 2020, Vol. 4 No. 01

\section{Daftar Pustaka}

Fitriana, R., Nur, D. R., \& Arbain, A. (2017). Pelatihan dan Simulasi IELTS bagi Mahasiswa dan Dosen di Lingkungan Fakultas Pendidikan dan Keguruan Program Studi Bahasa Inggris Universitas Widya Gama Mahakam Samarinda. Jurnal Abdimas Mahakam, 1(2), 88-95.

Pernyata, Syafruddin. 2012. Belajar Dari Universitas Kehidupan. Samarinda : Pustaka Spirit.

Sefrina, Andin. 2013. Deteksi Minat dan Bakat Anak.Jakarta: Media Pressindo.

Sugiyono. 2010. Metode Penelitian Kuantitatif, Kualitatif, dan R\&D. Bandung: Alfabeta.

Suharsimi Arikunto. 2010. Prosedur Penelitian: Suatu Pendekatan Praktik. Jakarta: Rineka Cipta.

Sukardi. 2007. Metodologi Penelitian Pendidikan: Kompetensi dan Praktiknya. Jakarta: Bumi Aksara. 